\title{
Survey for the Incidence of Fusarium Wilt and Root Knot Nematode Complex of Tomato in North Eastern Karnataka, India
}

\author{
I.N. Jayanta ${ }^{1 *}$, S.B. Mallesh ${ }^{2}$, B. Zaheer Ahamed ${ }^{3}$, Y.S. Amaresh ${ }^{4}$, \\ S.C. Sreedevi ${ }^{5}$ and G. Ramesh ${ }^{6}$
}

${ }^{1}$ Department of Plant Pathology, AC Raichur, UAS Raichur, Karnataka, India

${ }^{2}$ Department of Plant Pathology, ARS, Hagari, Ballari, Karnataka, India

${ }^{3}$ Department of Plant Pathology, KVK, Kalaburgi, Karnataka, India

${ }^{4}$ Department of Plant Pathology, AC, Raichur, Karnataka, India

${ }^{5}$ AICRP, Groundnut, MARS, Raichur, Karnataka, India

${ }^{6}$ Department of Horticulture, AC, Raichur, Karnataka, India

*Corresponding author

\section{A B S T R A C T}

\begin{tabular}{|l|}
\hline Ke y w or d s \\
Tomato, Wilt, Fusarium \\
$\begin{array}{l}\text { oxysporum f. sp. } \\
\text { lycopersici, Meloidogyne } \\
\text { incognita, Survey }\end{array}$ \\
\hline Article Info \\
\hline $\begin{array}{l}\text { Accepted: } \\
16 \text { August } 2018 \\
\text { Available Online: } \\
\text { 10 September } 2018\end{array}$ \\
\hline
\end{tabular}

Tomato (Solanum lycopersicum Mill.) is the most popular vegetable world-wide. It is used as a fresh vegetable and also can be processed and canned in the form of paste, juice, sauce, powder or as a whole. The ripe fruits are good source of vitamin A, B and C which add a wide range of colour and flavour to the food. Recently, it started gaining more medicinal value because of the antioxidant property of ascorbic acid and lycopene content. The tomato is known to be affected by different diseases caused by fungi, bacteria, viruses and nematodes. Among different diseases affecting tomato, root-knot and wilt complex caused by Meloidogyne incognita and Fusarium oxysporum f. sp. lycopersici was observed in severe form. A survey was conducted in four districts of North Eastern Karnataka. The survey results revealed that disease incidence was noticed throughout the North Eastern Karnataka viz., Raichur, Yadagir, Kalaburgi and Koppal districts wherever tomato was grown. In tomato, wilt was noticed in all locations surveyed with a range of 8.33 to 38.66 per cent. Maximum wilt incidence was observed in Kalaburgi district (26.21\%) and least incidence was in Raichur district $(21.25 \%)$.

\section{Introduction}

Tomato (Solanum lycopersicum Mill.) belonging to the nightshade family i.e., solanaceae, is one of the most important popular vegetable in the world. It is a native of Peru in South America and the word tomato comes from the Aztec word Tomatl. This crop spread to North America, primarily by migrating birds and then the crop spread to different countries. Spanish priests introduced the tomato crop to Europe around 1550. In Europe it was known as PomaamorisAmorous apple or love apple. It was also known as Pomaperuviana, apple of Peru. It was Robert Gibbon Johanson, an ordinary farmer in the U.S.A who first ate tomato on a hot day of August, 1820 to demonstrate its 
edibility. From then onwards, the tomato spread throughout the world.

Global tomato production is currently around 170.75 million tons and China is the leading country both in area ( 1 million ha) and production (52.72 million tons). India ranks second with production of 21.24 million tons followed by USA, Turkey and Egypt. In India top five tomato producing states are Madhya Pradesh, Karnataka, Andhra Pradesh, Telangana and Gujarat. Karnataka has an area of 63.73 thousand ha and annual production of about 2138.13 thousand tons with an average productivity of 33.55 tons/ha (Anon., 2017).

Among the fungal diseases, Fusarium wilt is the most important disease and is a limiting factor in tomato production (Sokhi et al., 1991). Fusarium oxysporum f. sp. lycopersici is a soil borne pathogen that is highly specific to tomato and is worldwide in distribution (Walker, 1969).

Among the nematode diseases in tomato, root knot nematode (Meloidogyne species), sting nematode (Belonolaimus longicaudatus), stubby-root nematode (Paratrichodorus and Trichodorus spp.) and lesion nematode (Pratylenchus sp.) are important. Of these, root knot nematode ( $M$. incognita) is the most dominant species accounting for 64 per cent of total population which is widely prevalent inflicting serious loss to tomato fruit yield (Sasser, 1980).

\section{Materials and Methods}

A random survey was conducted in major tomato growing areas of North Eastern Karnataka viz., Raichur, Yadagir, Kalaburgi and Koppal districts during kharif 2017. Samples of soil and roots were collected from sufficiently wet fields from the rhizospheres of tomato. In the similar manner, totally 10 spots were selected randomly for taking infected soil and plant samples representing the whole field. Later from this, a composite sample of $200 \mathrm{~g}$ of soil and $5 \mathrm{~g}$ of root were formed. Randomly 100 plants were selected in different locations in a field and number of plants wilted was counted and the mean wilt incidence was expressed in percentage. Completely wilted plants were also collected. The per cent disease incidence was calculated by using the formula.

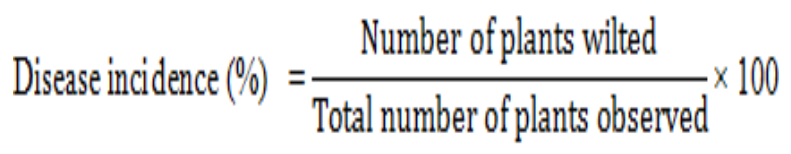

Wilted/nematode affected tomato plants were collected from the field, placed in polythene bag, tied with a rubber band and labeled immediately. Information pertaining to the locality, crop history, etc. was also obtained along with the samples. Collected samples of soil and roots were analyzed on the same day or after keeping for a few days under refrigerated conditions. The soil was mixed thoroughly and $200 \mathrm{cc}$ of soil was processed following Cobb's sieving and decanting method (Cobb, 1918) followed by modified Baermann's funnel method (Schindler, 1961).

\section{Results and Discussion}

A survey was conducted in four districts of North Eastern Karnataka. The survey results revealed that disease incidence was noticed throughout the North Eastern Karnataka viz., Raichur, Yadagir, Kalaburgi and Koppal districts wherever tomato was grown. During the survey, soil samples were collected.

In tomato, wilt was noticed in all locations surveyed with a range of 8.33 to 38.66 per cent. Maximum wilt incidence was observed in Kalaburgi district $(26.21 \%)$ and least incidence was in Raichur district (21.25\%). The data of per cent wilt incidence has been presented in Table 1. 
Table.1 Incidence of Fusarium wilt, root knot nematode and their wilt complex in major tomato growing areas of North Eastern Karnataka during kharif 2017

\begin{tabular}{|c|c|c|c|c|c|c|c|c|}
\hline $\begin{array}{l}\text { SI. } \\
\text { No }\end{array}$ & District & Taluk & Villages & $\begin{array}{l}\text { Number } \\
\text { of } \\
\text { samples }\end{array}$ & $\begin{array}{l}\text { Meloidogyne } \\
\text { incognita (M) }\end{array}$ & $\begin{array}{l}\text { Fusarium } \\
\text { (F) }\end{array}$ & $\mathbf{M}+\mathrm{F}$ & $\begin{array}{l}\text { Disease incidence (\%) } \\
(\mathrm{F}, \mathrm{M} \text { or } \mathrm{F}+\mathrm{M})\end{array}$ \\
\hline \multirow{11}{*}{1} & \multirow{11}{*}{ Kalaburgi } & \multirow{3}{*}{ Kalaburgi } & Nandur K & 3 & - & + & - & 8.33 \\
\hline & & & Ganajalakhed & 3 & + & + & + & 24.66 \\
\hline & & & Tajsultanpur & 3 & + & + & + & 31.66 \\
\hline & & & \multicolumn{5}{|l|}{ Mean } & 21.55 \\
\hline & & \multirow{3}{*}{ Chittapur } & Nalwar & 3 & + & + & + & 28.33 \\
\hline & & & Dandothi & 3 & - & + & - & 13.00 \\
\hline & & & Kaalagi & 3 & + & + & + & 31.00 \\
\hline & & & \multicolumn{5}{|l|}{ Mean } & 24.11 \\
\hline & & \multirow{3}{*}{ Aland } & Kadaganchi & 3 & + & + & + & 34.66 \\
\hline & & & Mogha K & 3 & + & + & + & 32.00 \\
\hline & & & Belamagi & 3 & + & + & + & 32.33 \\
\hline & & & \multicolumn{5}{|l|}{ Mean } & 32.99 \\
\hline & & & \multicolumn{5}{|l|}{ Grand mean } & 26.21 \\
\hline \multirow{9}{*}{2} & \multirow{9}{*}{ Yadagir } & \multirow{3}{*}{ Yadagir } & Tumkur & 3 & + & + & + & 25.00 \\
\hline & & & Mudnal & 3 & + & - & - & 10.66 \\
\hline & & & Hattikuni & 3 & + & + & + & 30.66 \\
\hline & & & \multicolumn{5}{|l|}{ Mean } & 22.10 \\
\hline & & \multirow{5}{*}{ Shahapur } & Hayyal & 3 & + & + & + & 34.33 \\
\hline & & & Chamnal & 3 & + & + & + & 38.66 \\
\hline & & & Khanapur & 3 & - & + & - & 22.00 \\
\hline & & & Mean & & & & & 31.66 \\
\hline & & & Krishnapur & 3 & - & + & - & 12.66 \\
\hline
\end{tabular}




\begin{tabular}{|c|c|c|c|c|c|c|c|c|}
\hline & & \multirow[t]{2}{*}{ Shorapur } & Sugooru & 3 & + & + & + & 23.00 \\
\hline & & & Hunsagi & 3 & + & + & + & 28.33 \\
\hline & & & \multicolumn{5}{|l|}{ Mean } & 21.33 \\
\hline & & & \multicolumn{5}{|l|}{ Grand mean } & 25.03 \\
\hline \multirow{12}{*}{3} & \multirow{11}{*}{ Raichur } & \multirow{4}{*}{ Raichur } & UAS campus & 3 & - & + & - & 10.00 \\
\hline & & & Chandrabanda & 3 & + & + & + & 30.00 \\
\hline & & & Kalmal & 3 & + & - & - & 14.33 \\
\hline & & & \multicolumn{5}{|l|}{ Mean } & 18.11 \\
\hline & & \multirow{4}{*}{ Manvi } & Kavital & 3 & + & + & + & 23.33 \\
\hline & & & Pamanakallur & 3 & + & + & + & 31.00 \\
\hline & & & Chikalparvi & 3 & - & + & - & 9.00 \\
\hline & & & \multicolumn{5}{|l|}{ Mean } & 21.11 \\
\hline & & \multirow{3}{*}{ Lingasugur } & Echanal & 3 & + & + & + & 33.00 \\
\hline & & & Chitranal & 3 & - & + & - & 13.66 \\
\hline & & & Bupura & 3 & + & + & + & 27.00 \\
\hline & & & \multicolumn{5}{|l|}{ Mean } & 24.55 \\
\hline & & & \multicolumn{5}{|l|}{ Grand mean } & 21.25 \\
\hline \multirow{11}{*}{4} & \multirow{11}{*}{ Koppal } & \multirow{3}{*}{ Koppal } & Ginigera & 3 & + & + & + & 32.66 \\
\hline & & & Basapura & 3 & + & - & - & 10.66 \\
\hline & & & Belvatagi & 3 & - & + & - & 13.00 \\
\hline & & & \multicolumn{5}{|l|}{ Mean } & 18.77 \\
\hline & & \multirow{3}{*}{ Yelaburga } & Bevoor & 3 & + & - & - & 15.33 \\
\hline & & & Nelajeri & 3 & + & + & + & 30.66 \\
\hline & & & Narasapur & 3 & + & + & + & 31.33 \\
\hline & & & \multicolumn{5}{|l|}{ Mean } & 25.77 \\
\hline & & \multirow{3}{*}{ Kustagi } & Menedal & 3 & + & + & + & 27.66 \\
\hline & & & Gouripura & 3 & - & + & - & 11.00 \\
\hline & & & Hulihyder & 3 & + & + & + & 34.00 \\
\hline & & & \multicolumn{5}{|l|}{ Mean } & 24.22 \\
\hline & & & \multicolumn{5}{|l|}{ Grand mean } & 22.92 \\
\hline
\end{tabular}


Fig.1 Incidence of Fusarium wilt, root knot nematode and their wilt complex in major tomato growing areas of North Eastern Karnataka

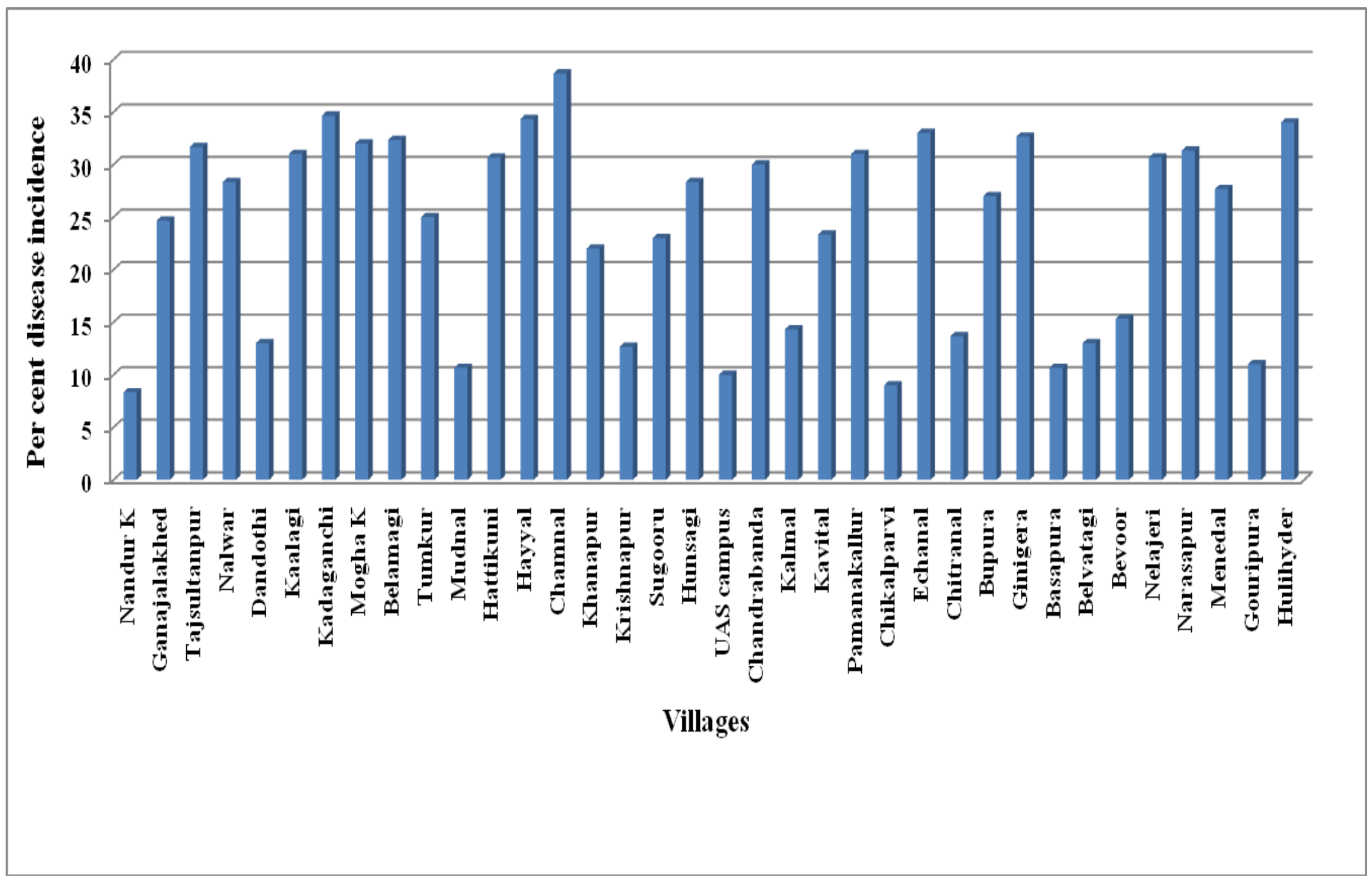


In Kalaburgi district, maximum disease incidence was observed in Kadaganchi village of Aland taluk (34.66\%) followed by Belamagivillage $(32.33 \%)$ and lowest was in Nandur K village of Kalaburgitaluk (8.33\%). In Yadagir district, maximum disease incidence was observed in Chamnal village of Shahapurtaluk (38.66\%) followed by Hayyal village $(34.33 \%)$ and lowest was in Mudnal village of Yadagirtaluk (10.66\%). In Raichur district, 33.00 per centof disease incidence was noticed from Echanal village of Lingasugurtaluk and 9.00 per cent incidence in Chikalparvi village of Manvitaluk. In Koppal district maximum disease incidence was observed in Hulihyder village of Kustagitaluk (34.00\%) and lowest incidence was in Gouripura village (11.00\%) (Fig. 1).

The findings of the present study revealed that wilt incidence was observed in all the districts surveyed. The incidence varied from village to village and field to field. This may be due to type of soil, variety of tomato grown, previous crop grown, moisture available in the field and management practices followed.

The present survey also indicated that the root knot disease caused by $M$. incognita was found in all the districts surveyed as well as its association with $F$. oxysporum f. sp. lycopersici in most of the locations surveyed with a high frequency of both the pathogens (M. incognita + F.oxysporum f. sp. lycopersici) from soil and root samples collected.

During survey, diseased samples were collected from different locations and pathogens were isolated. Fusarium oxysporum f. sp. lycopersici and M. incognita were isolated from all most all the locations collected and thus they proved to be the most predominant pathogens in tomato. Similar observations were also made in survey conducted by Mahesh (2016) in tomato,
Jagadish (2014) in tomato and Mallesh (2008) in coleus and ashwagandha at different parts of Karnataka. Krishna Rao and Krishnappa (1994) on chickpea in Karnataka, Pandey and Singh (1990) from Allahabad on chickpea, Sharma and McDonald (1990) from parts of the world also reported the association of nematode fungi in legumes and cereals, as well.

In general, wilt caused by F.oxysporum f. sp. lycopersici and $M$. incognita are one of the major constraints in the production of tomato crops. Very less or little information was available on the wilt complex of tomato in the North Eastern Karnataka region. Hence, a survey was undertaken to assess the wilt incidence of tomato in Kalaburgi, Yadagir, Raichur and Koppal districts. The data collected during the roving survey revealed that, maximum wilt incidence was observed in Chamnal (38.66 \%) village of Yadagir district and minimum wilt incidence in Nandur K $(8.33 \%)$ village of Kalaburgi district.

\section{References}

Anonymous, 2017, Horticulture Database, National Horticulture Board, Gurgoan, India, p. 453.

Cobb, N. A., 1918, Estimating the nematode population of soil. U.S. Department of Agriculture Circulation No. 1, p. 48.

Jagadish, G., 2014, Studies on root knot nematode and Fusarium wilt complex in tomato. M. Sc. (Agri.) Thesis, Univ. Agril. Sci., Raichur, Karnataka, India.

Krishna Rao, V. and Krishnappa, K., 1994, Interaction between Meloidogyne incognita and Fusarium oxysporum f. sp. ciceriat different inoculums levels on chickpea. Indian J. Nematol., 24 (2): $112-115$.

Mallesh, S. B., 2008, Plant growth promoting rhizobacteria, their characterization and 
mechanisms in the suppression of soil borne pathogens of coleus and ashwagandha. Ph.d Thesis, Univ. Agril. Sci., Dharwad., Karnataka, India.

Pandey, G. and Singh, R. B., 1990, Survey of root diseases of chickpea in Allahabad region. Curr. Nematol., 1: 77-78.

Sasser, J. N., 1980, Root-knot nematode: A global menace to crop production. PlantDisease, 63: 36-41.

Schindler*, A. F., 1961, A simple substitute for a Baermann funnel. Pl. Dis. Reporter, 48: 747- 748.

Sharma, S. B. and McDonald, D., 1990, Global status of nematode problems of groundnut, pigeonpea, chickpea, sorghum and pearl millet and suggestions for future work. Crop. Prot., 9: 453-458.

Sokhi, S. S., Munish, G. D., Grewal, R. K., Thind, T. S. and Sandhu, K. S., 1991, Current fungal disease problems of important vegetables in India, pp. 382404. In: Basic Research for crop disease management (Ed. Vidyasekharan, P.). Day Publishing House, New Delhi, 409 pp.

Walker, J. C., 1969, Plant Pathology. McGraw-Hill Book Co., New York, 819 pp.

\section{How to cite this article:}

Jayanta, I.N., S.B. Mallesh, B. Zaheer Ahamed, Y.S. Amaresh, S.C. Sreedevi and Ramesh, G. 2018. Survey for the Incidence of Fusarium Wilt and Root Knot Nematode Complex of Tomato in North Eastern Karnataka, India. Int.J.Curr.Microbiol.App.Sci. 7(09): 2060-2066. doi: https://doi.org/10.20546/ijcmas.2018.709.251 